OPEN ACCESS

Edited by:

David Paterson,

The University of

Queensland, Australia

Reviewed by:

Naveen Kumar Devanga Ragupathi, The University of Sheffield,

United Kingdom

Mario Venditti,

Sapienza University of Rome, Italy

*Correspondence:

David van Duin

david_vanduin@med.unc.edu

Specialty section:

This article was submitted to Infectious Diseases - Surveillance, Prevention and Treatment, a section of the journal Frontiers in Medicine

Received: 09 October 2020 Accepted: 04 January 2021 Published: 26 January 2021

Citation:

Tompkins K, Juliano JJ and van Duin D (2021) Antimicrobial Resistance in Enterobacterales and Its Contribution to Sepsis in Sub-saharan

Africa. Front. Med. 8:615649. doi: 10.3389/fmed.2021.615649

\section{Antimicrobial Resistance in Enterobacterales and Its Contribution to Sepsis in Sub-saharan Africa}

\author{
Kathleen Tompkins ${ }^{1}$, Jonathan J. Juliano ${ }^{1,2,3}$ and David van Duin ${ }^{1 *}$ \\ ${ }^{1}$ Division of Global Health and Infectious Diseases, University of North Carolina, Chapel Hill, NC, United States, ${ }^{2}$ Department \\ of Epidemiology, Gillings School of Global Public Health, University of North Carolina, Chapel Hill, NC, United States, \\ ${ }^{3}$ Curriculum in Genetics and Molecular Biology, School of Medicine, University of North Carolina, Chapel Hill, NC, \\ United States
}

Antibiotic resistant Enterobacterales (formerly Enterobactereaceae) are a growing threat to Sub-Saharan Africa. Genes causing antibiotic resistance are easily spread between the environment and humans and infections due to drug resistant organisms contribute to sepsis mortality via delayed time to appropriate antimicrobial therapy. Additionally, second or third-line antibiotics are often not available or are prohibitively expensive in resource-constrained settings leading to limited treatment options. Lack of access to water and sanitation facilities, unregulated use of antibiotics, and malnutrition are contributors to high rates of antibiotic resistance in the region. Improvements in the monitoring of drug resistant infections and antibiotic stewardship are needed to preserve the efficacy of antibiotics for the future.

Keywords: resistance, Klebsiella pneumoniae, E. coli, sepsis, Sub-Sahara Africa

\section{INTRODUCTION}

Globally, sepsis is estimated to cause an excess of 5 million deaths annually with low and middle income countries disproportionately affected (1). Sepsis is a significant problem in Sub-Saharan Africa (SSA) where mortality rates can be as high as $43 \%(2-4)$. While this high mortality is in part due to a lack of critical care resources being available in much of SSA (5), drug resistant pathogens play an important role in the increased mortality due to sepsis in this region.

Antimicrobial resistance (AMR) is a significant threat to human health that hampers our ability to treat a wide range of bacterial, parasitic, fungal, and viral infections (6). Antimicrobial resistance is recognized by the World Health Organization (WHO) as an increasingly serious threat to global public health that requires action across all government sectors and society (7). Although much of the research into AMR to date has been conducted in high-income countries (8), low and middle income countries (LMICs) bear a growing burden of AMR (9). Countries in SSA, in particular, are understudied in terms of rates and excess mortality due to AMR infections (10), yet experience a significant burden of disease $(11,12)$ and are expected to bear a disproportionate mortality burden (13). Additionally, parts of SSA have comparatively high rates of people living with HIV, which has been shown to increase the risk of invasive infection and subsequent sepsis $(14,15)$.

It is well-established that there are worse outcomes with drug-resistant infections in high-income countries (16-18). These poor outcomes can be exacerbated in low income regions where drug susceptibility testing can be delayed or absent and second or third-line antibiotics 
are either unavailable or prohibitively expensive (19). Additionally, AMR has been forecast to increase the number of people living in extreme poverty globally (20), exacerbated by global inequities and poor access to healthcare.

Enterobacterales (formerly Enterobacteriaceae) are of particular concern in SSA given their ability to rapidly colonize and spread (21-23) and the limited treatment options available for drug-resistant Enterobacterales in resource-constrained settings (24-26). Both the WHO and the CDC recognize drugresistant Enterobacterales as extremely concerning pathogens $(27,28)$. This review will focus on the rates and causes of AMR in Enterobacterales in SSA and the subsequent contribution to sepsis and mortality in the region. A limitation of this review is that more data are needed from future studies to more precisely estimate the rates and mechanisms of resistance in specific bacterial species, and the patient outcomes associated with infections caused by specific multidrug-resistant organisms.

\section{GENETIC DIVERSITY OF AMR IN SSA}

Antimicrobial resistance can occur through a variety of mechanisms. For Enterobacterales, resistance to the beta-lactam class of antibiotics is particularly concerning as beta-lactams are the cornerstone of treatment for these infections (29-31). Resistance to beta-lactam antibiotics can occur via efflux pumps, altered penicillin binding sites, and beta-lactamases which cleave the beta-lactam ring and inactivate the target antibiotic (32), with beta-lactamases being the primary means of resistance for cephalosporins and carbapenems. Development of resistance occurs through new mutations or upregulation and expression of existing genes, $A m p C$ being the most common occurrence of the later (33). Spread can then occur through clonal dissemination, horizontal gene transfer via plasmids, or translocation of resistance genes between mobile genetic elements $(32,34)$.

As AMR genes have spread worldwide they are now found throughout Africa in varying rates. The beta-lactamase genes bla $a_{C T X-M}$ are responsible for much of the spread for ESBLEnterobacterales (ESBL-E) worldwide (35-37). bla $a_{C T X-M}$ are most commonly transferred via plasmids (38), which allow for the spread of multiple resistance genes at one time (39). In Africa, rates of ESBL-E are increasing, largely as a result of CTX-M genes. A review of AMR isolates in East Africa found high rates of a variety of AMR genes, with the bla $a_{C T X-M}$ genes being the most common etiology of ESBL-E infection, found in $45.7 \%$ of isolates (40). A study in Ethiopia showed high rates of ESBL infections among gram negative isolates with $95 \%$ of those carrying CTX$M$ genes (41). High rates of CTX-M have similarly been found in studies from Nigeria (42), Tanzania $(43,44)$, Malawi $(45,46)$, and Ghana (47). Other ESBL-encoding genes including bla ${ }_{T E M}$, $b l a_{O X A}$, and $b l a_{S H V}$ are also found through the region $(40,46)$.

In addition to ESBL-producing organisms, carbapenemaseproducing organisms are a growing threat to the region. The carbapenemase gene KPC is the most prevalent carbapenemase in the United States (48), but is less frequently found in Africa (49). In contrast, the carbapenemase genes bla $a_{I M P}$, bla $a_{V I M}$, and bla $a_{O X A}$ appear to be more common in Africa $(40,50)$. For carbapenemase genes, it remains unclear if clonal expansion or horizontal transfer via plasmids are the primary means of dissemination (51), however they have been shown to spread easily and rapidly in hospitals and other healthcare settings (52). This is of particular concern in SSA where rapid diagnosis is not always possible and strict hygiene and infection control measures can be difficult to achieve $(53,54)$.

\section{BURDEN OF INTESTINAL AMR CARRIAGE IN SSA}

There is substantially less data characterizing the rates of AMR carriage and infection in SSA when compared to North America and Europe. Studies that have been done are primarily from urban areas, despite $60 \%$ of the population of SSA living in rural regions (55). Studies can be broadly categorized as those that determine rates of AMR carriage in community-dwelling (asymptomatic) individuals and those that are hospital-based and determine rates in patients with active infection.

Although infection rates are an obvious and important source of information to assess the contribution of AMR to sepsis in SSA, carriage rates are equally important, as intestinal colonization with AMR pathogens precedes and predicts subsequent infection. The intestinal microbiome is a well-described and important reservoir for AMR bacteria that may cause subsequent infections (56-58) and the likelihood of invasive AMR infections is dramatically increased in people who are colonized $(59,60)$.

Rates of intestinal AMR carriage can be studied in a variety of ways, which can make comparison between studies difficult, however rate of ESBL-E carriage is a common method. In SSA, rates of ESBL-E carriage vary widely by the region and specific population being studied, from 5 to $59 \%$. Carriage rates from a number of studies and their populations are summarized in Table 1. Notably, many of these studies include individuals with little to no healthcare exposure or antibiotic use, suggesting there is significant community spread.

\section{RATES OF AMR INFECTIONS IN HOSPITALIZED PATIENTS}

Asymptomatic carriage can be a precursor to disease, and, while there are fewer studies from SSA than from other regions, hospital infections with AMR pathogens is an important contributor to disease in this region. This is particularly relevant for bloodstream infections (BSI), as BSI remain a leading cause of death of both adults and children in the region (74). Ceftriaxone is often used empirically for sepsis in the region due to the relative ease of dosing and low cost. Thus, ceftriaxone resistance is particularly worrisome. The MERINO study showed that carbapenems are the preferred treatment option for invasive infections caused by ceftriaxone-resistant enteric bacteria (75). Unfortunately, carbapenems are not available to many patients with sepsis in SSA.

A recent meta-analysis of bloodstream infections in SSA found an overall prevalence rate of third generation cephalosporin resistance of $18.4 \%$ for Escherichia coli isolates and 
TABLE 1 | Studies evaluating rates of ESBL-E carriage in SSA.

\begin{tabular}{|c|c|c|c|}
\hline References & Country & Population & $\begin{array}{l}\text { Percent with } \\
\text { ESBL intestinal } \\
\text { carriage (\%) }\end{array}$ \\
\hline Sanneh et al. (61) & The Gambia & Food handlers & 5 \\
\hline Farra et al. (62) & $\begin{array}{l}\text { Central } \\
\text { African } \\
\text { Republic }\end{array}$ & $\begin{array}{l}\text { Children (age 0-59 } \\
\text { months) }\end{array}$ & 59 \\
\hline Mshana et al. (63) & Tanzania & Any age & 16.5 \\
\hline Chereau et al. (64) & Madagascar & $\begin{array}{l}\text { Pregnant women } \\
\text { at time of delivery }\end{array}$ & 18.5 \\
\hline Ribeiro et al. (65) & Angola & $\begin{array}{l}\text { Healthy } \\
\text { community } \\
\text { dwellers }\end{array}$ & 22.2 \\
\hline $\begin{array}{l}\text { Albrechtova et al. } \\
\text { (66) }\end{array}$ & Kenya & $\begin{array}{l}\text { Nomadic } \\
\text { pastoralists }\end{array}$ & 17 \\
\hline Tellevik et al. (67) & Tanzania & $\begin{array}{l}\text { Healthy children } \\
<2 \text { y/o }\end{array}$ & 11.6 \\
\hline Moremi et al. (68) & Tanzania & Street children & 31.8 \\
\hline $\begin{array}{l}\text { Chirindze et al. } \\
\text { (69) }\end{array}$ & Mozambique & University students & 20 \\
\hline Fortini et al. (70) & Nigeria & $\begin{array}{l}\text { Healthy pregnant } \\
\text { women on day of } \\
\text { admission }\end{array}$ & 31.7 \\
\hline Ruppé et al. (71) & Senegal & $\begin{array}{l}\text { Children in remote } \\
\text { village }\end{array}$ & 10 \\
\hline Lonchel et al. (72) & Cameroon & Student volunteers & 6.7 \\
\hline $\begin{array}{l}\text { Ouchar Mahamat } \\
\text { et al. (73) }\end{array}$ & Chad & $\begin{array}{l}\text { Healthy } \\
\text { community } \\
\text { volunteers }\end{array}$ & 38 \\
\hline
\end{tabular}

$54.5 \%$ for Klebsiella isolates (19). Some studies suggest the rates of drug resistance are increasing dramatically in the region. For example, a study of BSI from a large referral hospital in Malawi showed an increase in ESBL resistance from 0.7 to $30.3 \%$ of E. coli isolates and from 11.8 to $90.5 \%$ in Klebsiella spp. isolates between 1998 and 2016 (76). Similarly, they found methicillin resistance of Staph aureus isolates increased from 7.7 to $18.4 \%$ over the same period. More data are needed from future studies to more precisely estimate the rates and mechanisms of resistance in specific bacterial species, and the patient outcomes associated with infections caused by specific multidrug-resistant organisms.

\section{OUTCOMES OF AMR INFECTION IN HOSPITALIZED PATIENTS}

The dramatic rise in AMR detection is associated with worse outcomes. A study in pediatric patients at a hospital in Senegal showed that AMR carriage is associated with delayed time to appropriate antibiotics and a substantial increase in mortality from 15.4 to $54.8 \%$ in patients with ESBL-producing Enterobacterales BSI compared to susceptible strains (77). This was confirmed by another study from Tanzania which found AMR to be an independent risk factor for mortality in both children and adults with BSI, with mortality rates increasing from 13.7 to $48.4 \%$ when organisms were multidrug resistant compared to those that were susceptible (78). Similarly, a study of adult patients in Ethiopia showed significant increase in mortality with BSI if the isolate was resistant to third generation cephalosporins, with all patients with resistant infection in that study having died (79).

Aside from BSI, resistance presents a challenge to other infections as well. Clinical isolates from multiple sources including wound, urine, blood, and sputum at a large Rwandan hospital showed $75.9 \%$ of isolates were resistant to ceftriaxone, a third generation cephalosporin (80). A study of clinical isolates growing Klebsiella pneumoniae from Cote d'Ivoire likewise showed high prevalence of ESBL resistance, at $84 \%$ of all isolates and $94 \%$ of pediatric isolates (81). These findings have implications for the treatment of urinary tract infections, wound infections, and surgical infections, among others.

Although many patients present from the community with AMR infections, hospital acquisition is a common means of becoming infected or colonized with AMR pathogens and can occur soon after admission. A study from Rwanda looking at ESBL-E acquisition during hospitalization found that overall carriage rates in patients increased from $49.7 \%$ on admission to $64.6 \%$ on discharge, however this number was as high as $93 \%$ on discharge from the pediatric unit (82). Another study of neonates in Kenya showed that 55\% acquired ESBL carriage during hospitalization (83).

\section{DRIVERS OF AMR IN SSA}

AMR is driven by multiple factors, however overconsumption with unnecessary or inappropriate use of antibiotics is a significant contributor (84). Consumption of antibiotics varies widely between regions, however, as many as half of all antibiotics in developing countries being used inappropriately (85). A recent WHO report from a limited number of countries in Africa shows rates of antibiotic consumption that range from 4.4 to 27.3 daily doses per day per 1,000 inhabitants (86). Notably, this only includes antibiotics dispensed through regulated agencies, not unregulated or non-prescription sales. Dispending antibiotics without a prescription is a common occurrence in much of Africa. In one region of Tanzania, over $88 \%$ of antibiotic prescription were found to be irrational with $76 \%$ occurring without a prescription (87) and in Cameroon $47 \%$ of antibiotics dispensed at pharmacies were without a prescription (88). This lack of regulation and consumption of inappropriate and nonprescription antibiotics is a contributor to the spread of drug resistance in the region (89-92).

Human consumption of antibiotics is only one driver of AMR. Livestock and veterinary overuse of antibiotics for commercial farming are a large contributor of AMR worldwide $(93,94)$ and this holds true in SSA as well (95). The idea that humans, animals, and the environment are connected and all contribute to the health of society is termed a "One Health" approach (96). Antibiotics used in farming practices are discharged into the environmental through animal waste where they contribute to the "resistome" of the environment and can lead to human colonization or infection with AMR pathogens, raising the overall 
AMR burden in communities (97). Antibiotic use in commercial animal farming has largely focused on Europe, North America, and certain middle income countries including China, Brazil, and India where use rates are high (98), however high rates of antibiotic use and subsequent AMR have been found in SSA ranging from 74 to $100 \%$ of farms (99), with little to no surveillance systems in place on national levels to ensure accurate tracking of use (100). Additionally, antibiotic use for livestock worldwide is expected to rise significantly in the coming years, including in SSA, with an estimated $67 \%$ increase to 105,000 tons by 2030 (93).

The multidisciplinary nature of AMR was highlighted by a recent study showing that the spread of AMR genes (as opposed to selective bacterial pressure) may be the dominant factor contributing to high rates of AMR in the region (101). To this end, improving access to safe drinking water and sanitation facilities (102) are urgently needed to help limit AMR (103).

In addition to the above, malnutrition may also contribute to AMR in SSA, particularly in the pediatric population. It is wellestablished that malnutrition places individuals at increased risk for infection (104) and thus is may facilitate the spread of AMR genes (105). Additionally, malnutrition may place individuals at greater risk specifically for drug-resistant infections. In Senegal, malnutrition was associated with twice the risk for contracting an ESBL-BSI compared to a susceptible BSI (77). Similarly, another study found high rates of multidrug resistant urinary tract infections in malnourished children in Tanzania (106).

Africa has the highest number of people living with HIV (PLWH) in the world. There is growing evidence that HIV may increase the carriage rates of AMR bacteria in the GI tract (107), a precursor to invasive infection. Two studies of pediatric patients hospitalized in South Africa with BSI found that HIV infection was associated with increased likelihood of having a resistant isolate and a corresponding increase in sepsis-related mortality $(108,109)$. Similarly, a study of pediatric bacteremia in Tanzania found children living with HIV were more likely to receive inappropriate initial antimicrobial therapy due to drug resistance and subsequently had a higher risk of mortality compared with their HIV negative counterparts (110).

\section{GLOBAL IMPORTANCE OF AMR}

Although this review focuses on AMR and its contribution to sepsis in SSA, drug resistance is a global problem that extends beyond national borders. As travel and immigration lead to increasing globalization, AMR genes can quickly spread worldwide (23). A recent meta-analysis found that a quarter of migrants to Europe were colonized with multi-drug resistant

\section{REFERENCES}

1. Fleischmann C, Scherag A, Adhikari NKJ, Hartog CS, Tsaganos T, Schlattmann P, et al. Assessment of global incidence and mortality of hospital-treated sepsis. Current Estimates and Limitations. Am J Respir Crit Care Med. (2016) 193:259-72. doi: 10.1164/rccm.201504-0781OC organisms, with the rate being higher in asylum seekers (21). Similarly, a study of Eritrean migrants in Europe showed high rates of gram negative and polymicrobial carriage with AMR genes detected (111). International travel is also a means of dissemination, with $24 \%$ of returning Swedish travelers carrying CTX-M-15 (112) and a meta-analysis showing overall acquisition of ESBL organisms among travelers to Africa to be over 15\%, with wide variation between regions and higher rates in those who experienced travelers diarrhea or used fluoroquinolone antibiotics while abroad (113). In addition, acquisition is not confined to the traveler, as another study showed the probability of transmitting AMR genes to another household member after return was $12 \%$ (114), indicating the potential for dissemination to the surrounding community.

\section{CONCLUSIONS}

Antimicrobial resistance is growing as a worldwide threat and contributes to sepsis-associated mortality, with alarming rates in SSA. Moving forward, a global coordinated response is needed to halt the spread of AMR and improve outcomes for patients with sepsis due to these organisms in SSA. To this end, the World Health Organization developed the Global Action Plan Against Antimicrobial Resistance in 2015 to create a framework for member states to focus research and resources on AMR while attempting to reduce the need for antibiotics through improved infection prevention and sanitation (115). That same year, the WHO launched the Global Antimicrobial Resistance Surveillance System (GLASS) to uniformly track rates of AMR worldwide and estimate the attributable mortality due to AMR (116). As AMR continues to pose a threat to human health across the world it is clear that a multi-pronged approach is needed to halt the spread. This will require cooperation between countries and across disciplines and is imperative to ensure the continued efficacy of antimicrobials.

\section{AUTHOR CONTRIBUTIONS}

KT, JJ, and DD searched and reviewed the literature, summarized the data, and reviewed and edited the final content. KT wrote the first draft of the paper. All authors contributed to the article and approved the submitted version.

\section{FUNDING}

KT was supported by the National Institute of Health T32 grant (2T32AI007151). for care and research. Lancet Infect Dis. (2009) 9:577-82. doi: 10.1016/S1473-3099(09)70135-5

3. Jacob ST, Moore CC, Banura P, Pinkerton R, Meya D, Opendi P, et al. Severe sepsis in Two Ugandan hospitals: a prospective observational study of 
management and outcomes in a predominantly HIV-1 infected population. PLoS ONE. (2009) 4:e7782. doi: 10.1371/journal.pone.0007782

4. Lewis JM, Feasey NA, Rylance J. Aetiology and outcomes of sepsis in adults in sub-Saharan Africa: a systematic review and meta-analysis. Crit Care. (2019) 23:212. doi: 10.1186/s13054-019-2501-y

5. For the Global Intensive Care Working Group of the European Society of Intensive Care Medicine, Schultz MJ, Dunser MW, Dondorp AM, Adhikari NKJ, Iyer S, et al. Current challenges in the management of sepsis in ICUs in resource-poor settings and suggestions for the future. Intensive Care Med. (2017) 43:612-24. doi: 10.1007/s00134-017-4750-z

6. Prestinaci F, Pezzotti P, Pantosti A. Antimicrobial resistance: a global multifaceted phenomenon. Pathog Glob Health. (2015) 109:309-18. doi: 10.1179/2047773215Y.0000000030

7. Antimicrobial Resistance. The World Health Organization. Available online at: https://www.who.int/news-room/fact-sheets/detail/antimicrobialresistance (accessed September 9, 2020).

8. Jawad I, Lukšić I, Rafnsson SB. Assessing available information on the burden of sepsis: global estimates of incidence, prevalence and mortality. $J$ Glob Health. (2012) 2:010404. doi: 10.7189/jogh.01.010404

9. Essack SY, Desta AT, Abotsi RE, Agoba EE. Antimicrobial resistance in the WHO African region: current status and roadmap for action. J Public Health (Oxf). (2017) 39:8-13. doi: 10.1093/pubmed/fdw015

10. Tadesse BT, Ashley EA, Ongarello S, Havumaki J, Wijegoonewardena M, González IJ, et al. Antimicrobial resistance in Africa: a systematic review. BMC Infect Dis. (2017) 17:616. doi: 10.1186/s12879-017-2713-1

11. Bernabé KJ, Langendorf C, Ford N, Ronat J-B, Murphy RA. Antimicrobial resistance in West Africa: a systematic review and meta-analysis. Int $J$ Antimicrob Agents. (2017) 50:629-39. doi: 10.1016/j.ijantimicag.2017.07.002

12. Williams PCM, Isaacs D, Berkley JA. Antimicrobial resistance among children in sub-Saharan Africa. Lancet Infect Dis. (2018) 18:e33-44. doi: 10.1016/S1473-3099(17)30467-X

13. O'neill. Tackling Drug Resistant Infections Globally: Final Report and Recommendations. Review on Antimicrobial Resistance. (2016). Available online at: https://amr-review.org/sites/default/files/160518_Final\%20paper_ with\%20 cover.pdf (accessed September 10, 2020).

14. Huson MAM, Stolp SM, van der Poll T, Grobusch MP. Community-acquired bacterial bloodstream infections in HIV-infected patients: a systematic review. Clin Infect Dis. (2014) 58:79-92. doi: 10.1093/cid/cit596

15. Taramasso L, Tatarelli P, Di Biagio A. Bloodstream infections in HIV-infected patients. Virulence. (2016) 7:320-8. doi: 10.1080/21505594.2016.1158359

16. Pop-Vicas A, Opal SM. The clinical impact of multidrug-resistant gramnegative bacilli in the management of septic shock. Virulence. (2014) 5:206-12. doi: 10.4161/viru.26210

17. Ramphal R, Ambrose PG. Extended-spectrum $\beta$-lactamases and clinical outcomes: current data. Clin Infect Dis. (2006) 42(Suppl. 4):S164-72. doi: $10.1086 / 500663$

18. Rodríguez-Baño J, Pascual A. Clinical significance of extended-spectrum [beta]-lactamases. Expert Review Anti Infect Ther London. (2008) 5:671-83. doi: 10.1586/14787210.6.5.671

19. Lester R, Musicha P, van Ginneken N, Dramowski A, Hamer DH, Garner P, et al. Prevalence and outcome of bloodstream infections due to third-generation cephalosporin-resistant Enterobacteriaceae in sub-Saharan Africa: a systematic review. J Antimicrob Chemother. (2020) 75:492-507. doi: $10.1093 / \mathrm{jac} / \mathrm{dkz} 464$

20. Drug Resistant Infections: A Threat to our Economic Future. The World Bank (2017). Available online at: http://documents1.worldbank.org/curated/ en/323311493396993758/pdf/final-report.pdf (accessed September 9, 2020).

21. Nellums LB, Thompson H, Holmes A, Castro-Sánchez E, Otter JA, Norredam M, et al. Antimicrobial resistance among migrants in Europe: a systematic review and meta-analysis. Lancet Infect Dis. (2018) 18:796-811. doi: 10.1016/S1473-3099(18)30219-6

22. Frost I, Van Boeckel TP, Pires J, Craig J, Laxminarayan R. Global geographic trends in antimicrobial resistance: the role of international travel. J Travel Med. (2019) 26:taz036. doi: 10.1093/jtm/taz036

23. Gao R, Hu Y, Li Z, Sun J, Wang Q, Lin J, et al. Dissemination and mechanism for the MCR-1 colistin resistance. PLoS Pathog. (2016) 12:e1005957. doi: 10.1371/journal.ppat.1005957
24. Khuluza F, Heide L. Availability and affordability of antimalarial and antibiotic medicines in Malawi. PLoS ONE. (2017) 12:e017599. doi: 10.1371/journal.pone.0175399

25. Lufesi NN, Andrew M, Aursnes I. Deficient supplies of drugs for life threatening diseases in an African community. BMC Health Serv Res. (2007) 7:86. doi: 10.1186/1472-6963-7-86

26. Laxminarayan R, Matsoso P, Pant S, Brower C, Røttingen J-A, Klugman K, et al. Access to effective antimicrobials: a worldwide challenge. Lancet. (2016) 387:168-75. doi: 10.1016/S0140-6736(15)00474-2

27. Tacconelli E, Carrara E, Savoldi A, Harbarth S, Mendelson M, Monnet DL, et al. Discovery, research, and development of new antibiotics: the WHO priority list of antibiotic-resistant bacteria and tuberculosis. Lancet Infect Dis. (2018) 18:318-27. doi: 10.1016/S1473-3099(17)30753-3

28. Centers for Disease Control and Prevention (U.S.). Antibiotic Resistance Threats in the United States. (2019). Available online at: https://stacks.cdc. gov/view/cdc/82532 (accessed October 2, 2020).

29. Paterson DL. Impact of antibiotic resistance in gram-negative bacilli on empirical and definitive antibiotic therapy. Clin Infect Dis. (2008) 47(Suppl. 1):S14-20. doi: 10.1086/590062

30. Kalil AC, Metersky ML, Klompas M, Muscedere J, Sweeney DA, Palmer LB, et al. Management of adults with hospital-acquired and ventilatorassociated pneumonia: 2016 clinical practice guidelines by the Infectious Diseases Society of America and the American Thoracic Society. Clin Infect Dis. (2016) 63:e61-111. doi: 10.1093/cid/ciw353

31. Solomkin JS, Mazuski JE, Bradley JS, Rodvold KA, Goldstein EJC, Baron EJ, et al. Diagnosis and management of complicated intra-abdominal infection in adults and children: guidelines by the surgical infection society and the infectious diseases society of America. Clin Infect Dis. (2010) 50:133-64. doi: $10.1086 / 649554$

32. Pfeifer Y. Resistance to cephalosporins and carbapenems in Gramnegative bacterial pathogens. Int J Med Microbiol. (2010) 300:371-9. doi: 10.1016/j.ijmm.2010.04.005

33. Barlow M, Hall BG. Origin and evolution of the AmpC $\beta$-lactamases of Citrobacter freundii. Antimicrob Agents Chemother. (2002) 46:1190-8. doi: 10.1128/AAC.46.5.1190-1198.2002

34. Peirano G, Pitout JDD. Extended-spectrum $\beta$-lactamase-producing Enterobacteriaceae: update on molecular epidemiology and treatment options. Drugs. (2019) 79:1529-41. doi: 10.1007/s40265-019-01180-3

35. Ludden C, Decano AG, Jamrozy D, Pickard D, Morris D, Parkhill J, et al. Genomic surveillance of Escherichia coli ST131 identifies local expansion and serial replacement of subclones. Microb Genom. (2020) 6:e.000352. doi: 10.1099/mgen.0.000352

36. Matsumura Y, Pitout JDD, Peirano G, DeVinney R, Noguchi T, Yamamoto $\mathrm{M}$, et al. Rapid identification of different Escherichia coli sequence type 131 clades. Antimicrob Agents Chemother. (2017) 61:e00179-17. doi: 10.1128/AAC.00179-17

37. Cantón R, González-Alba JM, Galán JC. CTX-M enzymes: origin and diffusion. Front Microbiol. (2012) 3:110. doi: 10.3389/fmicb.2012.00110

38. Barlow M, Reik RA, Jacobs SD, Medina M, Meyer MP, McGowan JE, et al. High rate of mobilization for blaCTX-Ms. Emerg Infect Dis. (2008) 14:423-8. doi: 10.3201/eid1403.070405

39. Paterson DL, Bonomo RA. Extended-spectrum $\beta$-lactamases: a clinical update. Clin Microbiol Rev. (2005) 18:657-86. doi: 10.1128/CMR.18.4.657-686.2005

40. Katale BZ, Misinzo G, Mshana SE, Chiyangi H, Campino S, Clark TG, et al. Genetic diversity and risk factors for the transmission of antimicrobial resistance across human, animals and environmental compartments in East Africa: a review. Antimicrob Resist Infect Control. (2020) 9:127. doi: 10.1186/s13756-020-00786-7

41. Zeynudin A, Pritsch M, Schubert S, Messerer M, Liegl G, Hoelscher $M$, et al. Prevalence and antibiotic susceptibility pattern of CTX-M type extended-spectrum $\beta$-lactamases among clinical isolates of gramnegative bacilli in Jimma, Ethiopia. BMC Infect Dis. (2018) 18:524. doi: 10.1186/s12879-018-3436-7

42. Soge OO, Queenan AM, Ojo KK, Adeniyi BA, Roberts MC. CTX-M-15 extended-spectrum (beta)-lactamase from Nigerian Klebsiella pneumoniae. J Antimicrob Chemother. (2006) 57:24-30. doi: 10.1093/jac/dki429 
43. Mshana SE, Hain T, Domann E, Lyamuya EF, Chakraborty T, Imirzalioglu C. Predominance of Klebsiella pneumoniae ST14 carrying CTX-M-15 causing neonatal sepsis in Tanzania. BMC Infect Dis. (2013) 13:466. doi: 10.1186/1471-2334-13-466

44. Manyahi J, Moyo SJ, Tellevik MG, Ndugulile F, Urassa W, Blomberg B, et al. Detection of CTX-M-15 beta-lactamases in Enterobacteriaceae causing hospital- and community-acquired urinary tract infections as early as 2004, in Dar es Salaam, Tanzania. BMC Infect Dis. (2017) 17:282. doi: 10.1186/s12879-017-2395-8

45. Musicha P, Feasey NA, Cain AK, Kallonen T, Chaguza C, Peno C, et al. Genomic landscape of extended-spectrum $\beta$-lactamase resistance in Escherichia coli from an urban African setting. J Antimicrob Chemother. (2017) 72:1602-9. doi: 10.1093/jac/dkx058

46. Tegha G, Ciccone EJ, Krysiak R, Kaphatika J, Chikaonda T, Ndhlovu I, et al. Genomic epidemiology of Escherichia coli isolates from a Tertiary Referral Center in Lilongwe, Malawi. Microb Genom. (2020). doi: 10.1099/mgen.0.000490. [Epub ahead of print].

47. Quansah E, Barnie PA, Acheampong DO, Obiri-Yeboah D, Mills RO, Asmah E, et al. Geographical distribution of $\beta$-lactam resistance among Klebsiella spp. from selected health facilities in Ghana. Trop Med Infect Dis. (2019) 4:117. doi: $10.3390 /$ tropicalmed 4030117

48. Tracking CRE in the United States. Centers for Disease Control and Prevention. (2019). Available online at: https://www.cdc.gov/hai/organisms/ cre/trackingcre.html (accessed September 29, 2020).

49. Mushi MF, Mshana SE, Imirzalioglu C, Bwanga F. Carbapenemase genes among multidrug resistant gram negative clinical isolates from a Tertiary Hospital in Mwanza, Tanzania. BioMed Res Int. (2014) 2014:303104. doi: 10.1155/2014/303104

50. Manenzhe RI, Zar HJ, Nicol MP, Kaba M. The spread of carbapenemaseproducing bacteria in Africa: a systematic review. J Antimicrob Chemother. (2015) 70:23. doi: 10.1093/jac/dku356

51. Duin D van, Doi Y. The global epidemiology of carbapenemaseproducing Enterobacteriaceae. Virulence. (2017) 8:460. doi: 10.1080/21505594.2016.1222343

52. Nordmann P, Poirel L. The difficult-to-control spread of carbapenemase producers among Enterobacteriaceae worldwide. Clin Microbiol Infect. (2014) 20:821-30. doi: 10.1111/1469-0691.12719

53. Ogunsola FT, Mehtar S. Challenges regarding the control of environmental sources of contamination in healthcare settings in low-and middle-income countries-a narrative review. Antimicrob Resist Infect Control. (2020) 9:81. doi: 10.1186/s13756-020-00747-0

54. Sastry S, Masroor N, Bearman G, Hajjeh R, Holmes A, Memish Z, et al. The 17th International Congress on Infectious Diseases workshop on developing infection prevention and control resources for low- and middleincome countries. Int J Infect Dis. (2017) 57:138. doi: 10.1016/j.ijid.2017. 01.040

55. The World Bank. Rural Population (\% of Total Population) | Data. Available online at: https://data.worldbank.org/indicator/SP.RUR.TOTL.ZS? end=2019\&start=1988\&view=chart (accessed September 10, 2020).

56. Woerther P-L, Burdet C, Chachaty E, Andremont A. Trends in human fecal carriage of extended-spectrum $\beta$-lactamases in the community: toward the globalization of CTX-M. Clin Microbiol Rev. (2013) 26:744-58. doi: 10.1128/CMR.00023-13

57. Isendahl J, Giske CG, Hammar U, Sparen P, Tegmark Wisell K, Ternhag A, et al. Temporal dynamics and risk factors for bloodstream infection with extended-spectrum $\beta$-lactamase-producing bacteria in previously-colonized individuals: national population-based cohort study. Clin Infect Dis. (2019) 68:641-9. doi: 10.1093/cid/ciy539

58. Freeman JT, McBride SJ, Nisbet MS, Gamble GD, Williamson DA, Taylor SL, et al. Bloodstream infection with extended-spectrum betalactamase-producing Enterobacteriaceae at a tertiary care hospital in New Zealand: risk factors and outcomes. Int J Infect Dis. (2012) 16:e371-4. doi: 10.1016/j.ijid.2012.01.008

59. Cornejo-Juárez P, Suárez-Cuenca JA, Volkow-Fernández P, SilvaSánchez J, Barrios-Camacho H, Nájera-León E, et al. Fecal ESBL Escherichia coli carriage as a risk factor for bacteremia in patients with hematological malignancies. Support Care Cancer. (2016) 24:253-9. doi: $10.1007 / \mathrm{s} 00520-015-2772-\mathrm{z}$
60. Vehreschild MJGT, Hamprecht A, Peterson L, Schubert S, Hantschel $\mathrm{M}$, Peter S, et al. A multicentre cohort study on colonization and infection with ESBL-producing Enterobacteriaceae in high-risk patients with haematological malignancies. J Antimicrob Chemother. (2014) 69:3387-92. doi: $10.1093 / \mathrm{jac} / \mathrm{dku} 305$

61. Sanneh B, Kebbeh A, Jallow HS, Camara Y, Mwamakamba LW, Ceesay IF, et al. Prevalence and risk factors for faecal carriage of extended spectrum $\beta$-lactamase producing Enterobacteriaceae among food handlers in lower basic schools in West Coast Region of The Gambia. PLoS ONE. (2018) 13:e0200894. doi: 10.1371/journal.pone.0200894

62. Farra A, Frank T, Tondeur L, Bata P, Gody JC, Onambele M, et al. High rate of faecal carriage of extended-spectrum $\beta$-lactamase-producing Enterobacteriaceae in healthy children in Bangui, Central African Republic. Clin Microbiol Infect. (2016) 22:891.e1-.e4. doi: 10.1016/j.cmi.2016.07.001

63. Mshana SE, Falgenhauer L, Mirambo MM, Mushi MF, Moremi N, Julius R, et al. Predictors of blaCTX-M-15 in varieties of Escherichia coli genotypes from humans in community settings in Mwanza, Tanzania. BMC Infect Dis. (2016) 16:187. doi: 10.1186/s12879-016-1527-x

64. Chereau F, Herindrainy P, Garin B, Huynh B-T, Randrianirina F, Padget $\mathrm{M}$, et al. Colonization of extended-spectrum- $\beta$-lactamase- and NDM-1producing Enterobacteriaceae among pregnant women in the community in a low-income country: a potential reservoir for transmission of multiresistant Enterobacteriaceae to neonates. Antimicrob Agents Chemother. (2015) 59:3652-5. doi: 10.1128/AAC.00029-15

65. Ribeiro TG, Novais Â, Peixe L, Machado E. Atypical epidemiology of CTX-M-15 among Enterobacteriaceae from a high diversity of nonclinical niches in Angola. J Antimicrob Chemother. (2016) 71:1169-73. doi: $10.1093 / \mathrm{jac} / \mathrm{dkv} 489$

66. Albrechtova K, Dolejska M, Cizek A, Tausova D, Klimes J, Bebora L, et al. Dogs of nomadic pastoralists in Northern Kenya are reservoirs of plasmid-mediated cephalosporin- and quinolone-resistant Escherichia coli, including pandemic clone B2-O25-ST131. Antimicrob Agents Chemother. (2012) 56:4013-7. doi: 10.1128/AAC.05859-11

67. Tellevik MG, Blomberg B, Kommedal Ø, Maselle SY, Langeland N, Moyo SJ. High prevalence of faecal carriage of ESBL-producing Enterobacteriaceae among children in Dar es Salaam, Tanzania. PLoS ONE. (2016) 11:e0168024. doi: 10.1371/journal.pone.0168024

68. Moremi N, Claus H, Vogel U, Mshana SE. Faecal carriage of CTX$\mathrm{M}$ extended-spectrum beta-lactamase-producing Enterobacteriaceae among street children dwelling in Mwanza city, Tanzania. PLoS ONE. (2017) 12:e0184592. doi: 10.1371/journal.pone.0184592

69. Chirindze LM, Zimba TF, Sekyere JO, Govinden U, Chenia HY, Sundsfjord A, et al. Faecal colonization of E. coli and Klebsiella spp. producing extended-spectrum beta-lactamases and plasmid-mediated AmpC in Mozambican university students. BMC Infect Dis. (2018) 18:244. doi: 10.1186/s12879-018-3154-1

70. Fortini D, Fashae K, Villa L, Feudi C, García-Fernández A, Carattoli A. A novel plasmid carrying blaCTX-M-15 identified in commensal Escherichia coli from healthy pregnant women in Ibadan, Nigeria. J Glob Antimicrob Resist. (2015) 3:9-12. doi: 10.1016/j.jgar.2014.12.002

71. Ruppé E, Woerther P-L, Diop A, Sene A-M, Da Costa A, Arlet G, et al. Carriage of CTX-M-15-producing Escherichia coli isolates among children living in a remote village in Senegal. Antimicrob Agents Chemother. (2009) 53:3135-7. doi: 10.1128/AAC.00139-09

72. Lonchel CM, Meex C, Gangoué-Piéboji J, Boreux R, Assoumou M-CO, Melin P, et al. Proportion of extended-spectrum B-lactamase-producing Enterobacteriaceae in community setting in Ngaoundere, Cameroon. BMC Infect Dis. (2012) 12:53. doi: 10.1186/1471-2334-12-53

73. Ouchar Mahamat O, Tidjani A, Lounnas M, Hide M, Benavides J, Somasse C, et al. Fecal carriage of extended-spectrum $\beta$-lactamase-producing Enterobacteriaceae in hospital and community settings in Chad. Antimicrob Resist Infect Control. (2019) 8:169. doi: 10.1186/s13756-019-0626-z

74. Reddy EA, Shaw AV, Crump JA. Community-acquired bloodstream infections in Africa: a systematic review and meta-analysis. Lancet Infect Dis. (2010) 10:417-32. doi: 10.1016/S1473-3099(10)70072-4

75. Harris PN, Peleg AY, Iredell J, Ingram PR, Miyakis S, Stewardson AJ, et al. Meropenem vs. piperacillin-tazobactam for definitive treatment of bloodstream infections due to ceftriaxone non-susceptible Escherichia coli 
and Klebsiella spp. (the MERINO trial): study protocol for a randomised controlled trial. Trials. (2015) 16:24. doi: 10.1186/s13063-014-0541-9

76. Musicha P, Cornick JE, Bar-Zeev N, French N, Masesa C, Denis B, et al. Trends in antimicrobial resistance in bloodstream infection isolates at a large urban hospital in Malawi (1998-2016): a surveillance study. Lancet Infect Dis. (2017) 17:1042-52. doi: 10.1016/S1473-3099(17)30394-8

77. Ndir A, Diop A, Faye PM, Cissé MF, Ndoye B, Astagneau P. Epidemiology and burden of bloodstream infections caused by extended-spectrum betalactamase producing Enterobacteriaceae in a Pediatric Hospital in Senegal. PLoS ONE. (2016) 11:e0143729. doi: 10.1371/journal.pone.0143729

78. Manyahi J, Kibwana U, Mgimba E, Majigo M. Multi-drug resistant bacteria predict mortality in bloodstream infection in a tertiary setting in Tanzania. PLoS ONE. (2020) 15:e0220424. doi: 10.1371/journal.pone.0220424

79. Seboxa T, Amogne $\mathrm{W}$, Abebe $\mathrm{W}$, Tsegaye T, Azazh A, Hailu W, et al. High mortality from blood stream infection in Addis Ababa, Ethiopia, is due to antimicrobial resistance. PLoS ONE. (2015) 10:e0144944. doi: 10.1371/journal.pone.0144944

80. Sutherland T, Mpirimbanyi C, Nziyomaze E, Niyomugabo J-P, Niyonsenga $\mathrm{Z}$, Muvunyi CM, et al. Widespread antimicrobial resistance among bacterial infections in a Rwandan referral hospital. PLoS ONE. (2019) 14:e0221121. doi: 10.1371/journal.pone.0221121

81. Müller-Schulte E, Tuo MN, Akoua-Koffi C, Schaumburg F, Becker SL. High prevalence of ESBL-producing Klebsiella pneumoniae in clinical samples from central Côte d'Ivoire. Int J Infect Dis. (2020) 91:207-9. doi: 10.1016/j.ijid.2019.11.024

82. Kurz MSE, Bayingana C, Ndoli JM, Sendegeya A, Durst A, Pfüller R, et al. Intense pre-admission carriage and further acquisition of ESBL-producing Enterobacteriaceae among patients and their caregivers in a tertiary hospital in Rwanda. Trop Med Int Health. (2017) 22:210-20. doi: 10.1111/tmi.12824

83. Kagia N, Kosgei P, Ooko M, Wafula L, Mturi N, Anampiu K, et al. Carriage and acquisition of extended-spectrum $\beta$-lactamase-producing Enterobacterales among neonates admitted to hospital in Kilifi, Kenya. Clin Infect Dis. (2019) 69:751-9. doi: 10.1093/cid/ciy976

84. Cecchini M, Langer J, Slawomirski L. Antimicrobial Resistance in G7 Countries-and Beyond: Economic Issues, Policies and Options for Action. OECD (2015). Available online at: https://www.oecd.org/els/health-systems/ Antimicrobial-Resistance-in-G7-Countries-and-Beyond.pdf (accessed September 9, 2020).

85. Progress in the Rational Use of Medicines: Report by the Secretariat. World Health Organization (2007). Available online at: https://apps.who. int/gb/ebwha/pdf_files/WHA60/A60_24-en.pdf?ua=1 (accessed September 9, 2020).

86. WHO Report on Surveillance of Antibiotic Consumption: 2016-2018 Early Implementation. Geneva: World Health Organization (2018). Available online at: https://www.who.int/medicines/areas/rational_use/who-amramc-report-20181109.pdf (accessed September 9, 2020).

87. Mboya EA, Sanga LA, Ngocho JS. Irrational use of antibiotics in the Moshi Municipality Northern Tanzania: a cross sectional study. Pan Afr Med J. (2018) 31:165. doi: 10.11604/pamj.2018.31.165.15991

88. Elong Ekambi G-A, Okalla Ebongue C, Penda IC, Nnanga Nga E, Mpondo Mpondo E, Eboumbou Moukoko CE. Knowledge, practices and attitudes on antibiotics use in Cameroon: self-medication and prescription survey among children, adolescents and adults in private pharmacies. PLoS ONE. (2019) 14:e0212875. doi: 10.1371/journal.pone.0212875

89. Ocan M, Manabe YC, Baluku H, Atukwase E, Ogwal-Okeng J, Obua C. Prevalence and predictors of prior antibacterial use among patients presenting to hospitals in Northern Uganda. BMC Pharmacol Toxicol. (2015) 16:26. doi: 10.1186/s40360-015-0027-8

90. Afari-Asiedu S, Oppong FB, Tostmann A, Ali Abdulai M, Boamah-Kaali E, Gyaase S, et al. Determinants of inappropriate antibiotics use in Rural Central Ghana using a mixed methods approach. Front Public Health. (2020) 8:90. doi: $10.3389 /$ fpubh.2020.00090

91. Ocan M, Obuku EA, Bwanga F, Akena D, Richard S, Ogwal-Okeng J, et al. Household antimicrobial self-medication: a systematic review and metaanalysis of the burden, risk factors and outcomes in developing countries. BMC Public Health. (2015) 15:742. doi: 10.1186/s12889-015-2109-3

92. Morgan DJ, Okeke IN, Laxminarayan R, Perencevich EN, Weisenberg S. Non-prescription antimicrobial use worldwide: a systematic review.
Lancet Infect Dis. (2011) 11:692-701. doi: 10.1016/S1473-3099(11) 70054-8

93. Van Boeckel TP, Brower C, Gilbert M, Grenfell BT, Levin SA, Robinson TP, et al. Global trends in antimicrobial use in food animals. Proc Natl Acad Sci USA. (2015) 112:5649-54. doi: 10.1073/pnas.1503141112

94. Robinson TP, Bu DP, Carrique-Mas J, Fèvre EM, Gilbert M, Grace D, et al. Antibiotic resistance is the quintessential One Health issue. Trans $R$ Soc Trop Med Hyg. (2016) 110:377-80. doi: 10.1093/trstmh/trw048

95. Rousham EK, Unicomb L, Islam MA. Human, animal and environmental contributors to antibiotic resistance in low-resource settings: integrating behavioural, epidemiological and One Health approaches. Proc Biol Sci. (2018) 285:20180332. doi: 10.1098/rspb.2018.0332

96. McEwen SA, Collignon PJ. Antimicrobial Resistance: a One Health perspective. Microbiol Spectr. (2018) 6:2. doi: 10.1128/9781555819804.ch25

97. Finley RL, Collignon P, Larsson DGJ, McEwen SA, Li X-Z, Gaze WH, et al. The scourge of antibiotic resistance: the important role of the environment. Clin Infect Dis. (2013) 57:704-10. doi: 10.1093/cid/cit355

98. Manyi-Loh C, Mamphweli S, Meyer E, Okoh A. Antibiotic use in agriculture and its consequential resistance in environmental sources: potential public health implications. Molecules. (2018) 23:795. doi: 10.3390/molecules 23040795

99. Kimera ZI, Mshana SE, Rweyemamu MM, Mboera LEG, Matee MIN. Antimicrobial use and resistance in food-producing animals and the environment: an African perspective. Antimicrob Resist Infect Control. (2020) 9:37. doi: 10.1186/s13756-020-0697-x

100. Schar D, Sommanustweechai A, Laxminarayan R, Tangcharoensathien V. Surveillance of antimicrobial consumption in animal production sectors of low- and middle-income countries: optimizing use and addressing antimicrobial resistance. PLoS Med. (2018) 15:e1002521. doi: 10.1371/journal.pmed.1002521

101. Collignon P, Beggs JJ, Walsh TR, Gandra S, Laxminarayan R. Anthropological and socioeconomic factors contributing to global antimicrobial resistance: a univariate and multivariable analysis. Lancet Planet Health. (2018) 2:e398-405. doi: 10.1016/S2542-5196(18) 30186-4

102. Bürgmann H, Frigon D, Gaze WH, Manaia CM, Pruden A, Singer AC, et al. Water and sanitation: an essential battlefront in the war on antimicrobial resistance. FEMS Microbiol Ecol. (2018) 94:9. doi: 10.1093/femsec/ fiy 101

103. Fletcher S. Understanding the contribution of environmental factors in the spread of antimicrobial resistance. Environ Health Prev Med. (2015) 20:243. doi: 10.1007/s12199-015-0468-0

104. Walson JL, Berkley JA. The impact of malnutrition on childhood infections. Curr Opin Infect Dis. (2018) 31:231. doi: 10.1097/QCO.0000000000000448

105. Byarugaba DK. Antimicrobial resistance in developing countries and responsible risk factors. Int J Antimicrob Agents. (2004) 24:105-10. doi: 10.1016/j.ijantimicag.2004.02.015

106. Ahmed M, Moremi N, Mirambo MM, Hokororo A, Mushi MF, Seni J, et al. Multi-resistant gram negative enteric bacteria causing urinary tract infection among malnourished underfives admitted at a tertiary hospital, northwestern, Tanzania. Ital J Pediatr. (2015) 41:44. doi: 10.1186/s13052-015-0151-5

107. Marbou WJT, Kuete V. Bacterial resistance and immunological profiles in HIV-infected and non-infected patients at Mbouda AD LUCEM Hospital in Cameroon. J Infect Public Health. (2017) 10:269-76. doi: 10.1016/j.jiph.2016.04.009

108. Dramowski A, Cotton MF, Rabie H, Whitelaw A. Trends in paediatric bloodstream infections at a South African referral hospital. BMC Pediatr. (2015) 15:33. doi: 10.1186/s12887-015-0354-3

109. Buys H, Muloiwa R, Bamford C, Eley B. Klebsiella pneumoniae bloodstream infections at a South African children's hospital 2006-2011, a cross-sectional study. BMC Infect Dis. (2016) 16:570. doi: 10.1186/s12879-016-1919-y

110. Blomberg B, Manji KP, Urassa WK, Tamim BS, Mwakagile DS, Jureen R, et al. Antimicrobial resistance predicts death in Tanzanian children with bloodstream infections: a prospective cohort study. BMC Infect Dis. (2007) 7:43. doi: 10.1186/1471-2334-7-43

111. Ciccozzi M, Cella E, Ceccarelli G, Vita S, Dicuonzo G, Lopalco M, et al. Sentinel surveillance data from Eritrean migrants in Italy: The 
theory of "Healthy Migrants." Travel Med Infect Dis. (2018) 22:58-65. doi: 10.1016/j.tmaid.2017.09.004

112. Tängdén T, Cars $\mathrm{O}$, Melhus $\AA$, Löwdin E. Foreign travel is a major risk factor for colonization with Escherichia coli producing CTXM-type extended-spectrum $\beta$-lactamases: a prospective study with Swedish volunteers. Antimicrob Agents Chemother. (2010) 54:3564-8. doi: 10.1128/AAC.00220-10

113. Lääveri T, Vlot JA, van Dam AP, Häkkinen HK, Sonder GJB, Visser LG, et al. Extended-spectrum beta-lactamase-producing Enterobacteriaceae (ESBL-PE) among travellers to Africa: destination-specific data pooled from three European prospective studies. BMC Infect Dis. (2018) 18:341. doi: 10.1186/s12879-018-3245-z

114. Arcilla MS, van Hattem JM, Haverkate MR, Bootsma MCJ, van Genderen PJJ, Goorhuis A, et al. Import and spread of extended-spectrum [beta]-lactamase-producing Enterobacteriaceae by international travellers (COMBAT study): a prospective, multicentre cohort study. Lancet Infect Dis London. (2017) 17:78-85. doi: 10.1016/S1473-3099(16)30319-X

115. Global Action Plan on Antimicrobial Resistance. Geneva: World Health Organization (2015). Available online at: https://apps.who.int/iris/ bitstream/handle/10665/193736/9789241509763_eng.pdf?sequence $=1$ (accessed September 17, 2020).
116. National Antimicrobial Resistance Surveillance Systems and Participation in the Global Antimicrobial Resistance Surveillance System (GLASS). Geneva: World Health Organization (2016). Available online at: https://apps.who. int/iris/bitstream/handle/10665/251554/WHO-DGO-AMR-2016.4-eng. pdf? sequence $=1$ \&isAllowed $=y$ (accessed September 17, 2020).

Conflict of Interest: DD has served as a consultant for Achaogen, Allergan, Shionogi, Tetraphase, Pfizer, Merck, T2 Biosystems, Karius, Utility, Entasis, Qpex, and Roche.

The remaining authors declare that the research was conducted in the absence of any commercial or financial relationships that could be construed as a potential conflict of interest.

Copyright $\odot 2021$ Tompkins, Juliano and van Duin. This is an open-access article distributed under the terms of the Creative Commons Attribution License (CC BY). The use, distribution or reproduction in other forums is permitted, provided the original author(s) and the copyright owner(s) are credited and that the original publication in this journal is cited, in accordance with accepted academic practice. No use, distribution or reproduction is permitted which does not comply with these terms. 